\title{
PERAN GANDA PEREMPUAN DALAM USAHATANI TOMAT DI DESA TARAITAK SATU KECAMATAN LANGOWAN UTARA KABUPATEN MINAHASA
}

\author{
Vialli Erick Wowiling \\ Jenny Baroleh \\ Jean Fanny Junita Timban
}

\begin{abstract}
This study aims to determine the role of women in the stages of work on tomato farming and the time allocation in tomato farming and in household activities. This research was conducted for 6 months from November 2016 to May 2017 in Taraitak Satu Village, Langowan Utara District, Minahasa Regency. The data used in this study consisted of primary data obtained through interviews and observations on 20 women farmers who were deliberately selected by criteria of having a husband and working not as a tomato farmer. Secondary data was obtained from the Taraitak Satu Village Office, Unsrat Agricultural Library, the Internet through google searching in the form of a thesis from another university. Data analyzed using qualitative and quantitative analysis. Based on the results of the study concluded the stages of work involving women on tomato farming, namely the stage of seed preparation, land clearing, planting and making planting holes, planting, mulching, maintenance - including watering, weeding, fertilizing, controlling pests and diseases or spraying of pesticide, trimming and binding - , harvesting, and post-harvesting. The most dominant time allocation of female labor is at the maintenance stage except spraying drugs that are not carried out by women. Maintenance activities are carried out by women because according to the local community's views women are more diligent than men in this process namely watering, weeding, fertilizing, pruning and binding. The highest outpouring of women's work time in tomato farming is in maintenance activities, especially in binding and pruning activities, which requires 2 days per harvest where the period of 1 harvest is 3 months 2 weeks. In household activities: women with families devote time per day to work for income (tomato farming) an average of 8.3 hours per day while for housework time is 4.58 and for other activities such as worship is 4.2 hours per week. Women in the research location played a dual role as breadwinners (taking care of farming tomatoes) and at the same time as housewives who have to prepare their family's needs before going to take care of tomatoes. ${ }^{* \text { eprm* }}$
\end{abstract}

Keywords: multiple roles, women, tomato farming, Taraitak Satu Village, Minahasa Regency.

Penelitian ini bertujuan untuk mengetahui peran perempuan dalam tahap-tahap pekerjaan pada usahatani tomat dan curahan waktu dalam usahatani tomat dan dalam kegiatan rumah tangga. Penelitian ini dilaksanakan selama 6 bulan, yaitu bulan November 2016 sampai bulan Mei 2017 di Desa Taraitak Satu Kecamatan Langowan Utara Kabupaten Minahasa. Data yang digunakan dalam penelitian ini terdiri dari data primer yang diperoleh melalui wawancara dan pengamatan pada 20 responden petani perempuan yang dipilih secara sengaja, yaitu dengan kriteria memiliki suami dan bekerja bukan sebagai petani tomat. Data sekunder diperoleh dari Kantor Desa Taraitak Satu, Perpustakaan Pertanian Unsrat, Internet melalui google searching berupa skripsi dari universitas lain. Data di analisis menggunakan analisis kualitatif dan kuantitatif. Berdasarkan hasil penelitian disimpulkan tahap-tahap pekerjaan yang melibatkan perempuan pada usahatani tomat yaitu tahap persiapan bibit, pembersihan lahan, pembedengan dan pembuatan lubang tanam, penanaman, pemulsaan, pemeliharaan - termasuk penyiraman, penyiangan, pemupukan, pengendalian hama dan penyakit atau penyemprotan obat-obat, pemangkasan dan pengikatan -, panen, dan pasca panen. Curahan tenaga kerja perempuan yang paling dominan ada pada tahap pemeliharaan kecuali penyemprotan obat-obat yang tidak dilakukan oleh wanita Kegiatan pemeliharaan dilakukan oleh wanita karena menurut pandangan masyarakat setempat wanita lebih tekun dari laki-laki dalam proses ini yaitu penyiraman, penyiangan, pemupukan, pemangkasan dan pengikatan. Curahan waktu kerja perempuan tertinggi dalam usahatani tomat yaitu pada kegiatan pemeliharaan khususnya pada kegiatan pengikatan dan pemangkasan, yaitu memerlukan waktu 2 hari per panen dimana jangka waktu 1 kali panen adalah 3 bulan 2 minggu. Dalam kegiatan rumah tangga: wanita berkeluarga mencurahkan waktu per hari untuk pekerjaan nafkah (usaha tani tomat) rata-rata sebesar 8,3 jam per hari sedangkan untuk pekerjaan rumah tangga curahan waktu sebesar 4,58 dan untuk kegiatan lainnya seperti ibadah sebesar 4,2 jam per minggu. Wanita di desa penelitian melakukan peran ganda sebagai pencari nafkah (mengurus tomat) dan sekaligus sebagai ibu rumah tangga yang harus mempersiapkan kebutuhan keluarganya sebelum pergi mengurus tomat. ${ }^{*}$ eprm*

Kata kunci: peran ganda, perempuan, usahatani tomat, Desa Taraitak Satu, Kabupaten Minahasa

Agrisosioekonomi:

Jurnal Transdisiplin Pertanian (Budidaya Tanaman, Perkebunan, Kehutanan, Peternakan, Perikanan), Sosial dan Ekonomi 


\section{PENDAHULUAN}

\section{Latar Belakang}

Pertanian memegang peranan penting dalam perekonomian di Indonesia, karena sektor pertanian mampu memberikan pemulihan dalam mengatasi krisis yang terjadi. Oleh sebab itu pelaksanaan pembangunan pertanian merupakan salah satu upaya pemerintah dalam meningkatkan pertumbuhan ekonomi negara.

Sektor pertanian apabila dikembangkan secara terus menerus akan membawa dampak terhadap persoalan ketenaga kerjaan terutama tenaga kerja wanita. Tenaga kerja merupakan salah satu faktor yang digunakan didalam melaksanakan proses pertanian. Dalam kegiatan pertanian, tenaga kerja memperoleh pendapatan sebagai balas jasa dari usaha yang telah dilakukan yakni upah (Soetomo, 2008).

Dalam rumah tangga, biasanya perempuan yang menjadi pengelola dalam menyelesaikan proses pekerjaan domestik, karena perempuan dinilai lebih mampu bekerja dalam hal membersihkan dan memelihara lingkungan rumah tangganya seperti menyapu rumah, mencuci piring, memasak dan mengurus anak menjadi tanggung jawab perempuan. Pada keluarga yang kaya dan mampu, seringkali kerja domestik dibebankan pada pembantu rumah tangga yang biasanya adalah perempuan yang bekerja tanpa perlindungan dan tidak memiliki batas waktu. Sedangkan pada keluarga miskin, seluruh tanggungjawab kerja domestik harus dikerjakan oleh perempuan itu sendiri, dan seringkali perempuan juga harus mencari dan mencukupi hidup untuk keluarganya seperti contoh kebanyakan perempuan di desa melakukan tugas rutin dalam pengelolaan dan pemeliharaan rumah tangga, perempuan juga harus ke ladang untuk mencukupi kebutuhan ekonomi (Listiani, 2002).

Dalam suatu tatanan masyarakat selalu melekat status dan peran sosial seorang perempuan. Dalam tiap peran tersebut terdapat harapan-harapan tertentu, yang kadang-kadang antara suatu peran dan peran lainnya berseberangan sehingga terjadi konflik peran (Sugihastuti, 2000). Konflik merupakan situasi yang wajar dalam setiap masyarakat dan tidak ada satu masyarakat pun yang tidak mengalami konflik antar anggotanya atau dengan kelompok masyarakat lainnya. Konflik hanya akan hilang bersamaan dengan hilangnya masyarakat itu sendiri.

Perempuan seringkali diabaikan keberadaannya sebagai tenaga kerja yang produktif, walaupun dalam kenyataannya, perempuan secara fisik terlibat dalam proses produksi, pengolahan hasil, dan pemasaran hasil pertanian. Oleh karena itu perlu adannya pengembangan dan pemberdayaan perempuan.

Desa Taraitak Satu adalah salah satu desa di Kecamatan Langowan Utara yang merupakan sentra produksi tomat. Untuk pengelolaan usahatani tomat ini, tidak hanya pria saja yang terlibat didalamnya, tetapi semua anggota keluarga juga ikut berperan, baik istri maupun anak-anaknya. Selain bekerja sebagai ibu rumah tangga, para perempuan di Desa Taraitak Satu pada umumnya ikut terlibat dalam kegiatan usahatani tomat baik sebagai pemilik lahan, maupun sebagai buruh tani. Hal ini dilakukan, karena disamping untuk menghemat biaya produksi, tapi juga untuk menambah penghasilan keluarga mereka. Oleh karena itu, peneliti tertarik untuk meneliti sejauh mana peran ganda perempuan dalam usahatani tomat di Desa Taraitak Satu.

\section{Perumusan Masalah}

Dari uraian latar belakang, maka yang menjadi permasalahan dalam penelitian ini adalah:

1. Pada tahap-tahap pekerjaan apa saja perempuan itu dilibatkan dalam usahatani tomat?

2. Bagaimana curahan waktu kerja perempuan dalam usahatani tomat dan dalam kegiatan rumah tangga?

\section{Tujuan Penelitian}

1. Untuk mengetahui peranan perempuan dalam tahap-tahap pekerjaan pada usahatani tomat.

2. Curahan waktu dalam usahatani tomat dan dalam kegiatan rumah tangga.

\section{Manfaat Penelitian}

1. Penelitian ini bermanfaat untuk memberikan wawasan pengetahuan bagi penulis, mahasiswa dan masyarakat umum tentang peran perempuan dalam mensejahterakan keluarganya.

2. Penelitian ini sebagai salah satu kontribusi tanggungjawab akademik.

\section{METODE PENELITIAN}

\section{Tempat dan Waktu Penelitian}

Tempat penelitian yaitu di Desa Taraitak Satu, Kecamatan Langowan Utara, Kabupaten Minahasa. Adapun dasar pemilihan daerah penelitian ini karena di desa tersebut pada umumnya perempuan ikut terlibat dalam usahatani tomat.

Penelitian ini dilaksanakan selama 6 bulan yaitu bulan November 2016 sampai bulan Mei 2017, yang dimulai dari persiapan, pengambilan data sampai pada penyusunan laporan hasil penelitian.

\section{Metode Pengumpulan Data}

Data yang digunakan dalam penelitian ini terdiri dari data primer dan data sekunder. Data primer diperoleh secara langsung dari responden yang terkait dengan tahapan-tahapan pekerjaan dalam usahatani tomat. Teknik pengambilan data primer tersebut 
dengan menggunakan wawancara terhadap perempuan dengan kriteria memiliki suami dan bekerja bukan sebagai petani tomat.

Data sekunder diperoleh melalui dokumentasi, pengambilan data dan informasi dari instansi-instansi yang terkait yaitu dari Kantor Kecamatan, Kantor Kepala Desa serta literatur yang diperoleh dari perpustakaan ataupun internet.

\section{Metode Pengambilan Sampel}

Populasi dalam penelitian ini adalah petani perempuan yang mengusahakan lahan dengan tanaman tomat dan berperan sebagai istri yang memiliki suami. Pengambilan sampel dilakukan secara sengaja (purposive sampling), dimana peneliti memilih sendiri responden petani perempuan yang memiliki suami, dengan jumlah sampel sebanyak 20 responden perempuan.

\section{Konsep Pengukuran Variabel} adalah :

\section{Variabel yang dikaji dalam penelitian ini}

1. Identitas dan karakteristik responden:
a. Nama,
b. Umur responden (tahun),
c. Jenis kelamin,
d. Tingkat pendidikan,
e. Jumlah tanggungan dalam keluarga (orang),
f. Pengalaman bekerja,
g. Upah yang diperoleh (Rp/bulan),
h. Jumlah luas lahan yang ditanami tomat $\left(\mathrm{m}^{2}\right)$,
i. Jenis pekerjaan suami,
j. Pendapatan suami (Rp/bulan),
k. Pendapatan anak (jika sudah bekerja) (Rp/bulan),

2. Curahan waktu kerja yaitu lama waktu yang diperlukan dalam tahapan-tahapan pekerjaan usahatani tomat dan dalam menyelesaikan pekerjaan rumah tangganya (jam/hari),

a. Pekerjaan rumah tangga yang harus di selesaikan oleh perempuan dalam

hal ini ibu rumah tangga, seperti :

1) Membersihkan rumah,

2) Mencuci pakaian,

3) Ke pasar,

4) Memasak,

5) Mengurus anak dan suami,

6) Ke kebun,

7) Kegiatan dengan keluarga,

8) Kegiatan sosial.

b. Tahapan-tahapan pekerjaan yang melibatkan perempuan dalam usahatani tomat meliputi :
1) Persiapan bibit
2) Pembersihan lahan

3) Pembedengan dan pembuatan lubang

4) Pemulsaan

5) Penanaman

6) Pemeliharaan yang meliputi :
a. Penyiraman
b. Penyiangan
c. Pemupukan
d. Pemangkasan
e. Pengikatan

7) Panen dan pasca panen

\section{Metode Analisis Data}

Penelitian ini menggunakan metode analisis deskriptif yang disajikan dalam bentuk tabel, kemudian diinterpretasi untuk memperoleh gambaran mengenai peran ganda perempuan dalam usahatani tomat.

\section{HASIL DAN PEMBAHASAN}

\section{Deskripsi Daerah Penelitian}

\section{Luas dan Kondisi Geografis}

Penelitian ini dilakukan di Desa Taraitak Satu, Kecamatan Langowan Utara, Kabupaten Minahasa, Propinsi Sulawesi Utara. Kecamatan Langowan Utara merupakan salah satu dari kecamatan yang ada di Kabupaten Minahasa yang memiliki luas wilayah $11,18 \mathrm{~km}^{2}$, dan Desa Taraitak Satu merupakan salah satu dari 8 desa yang ada di Kecamatan Langowan Utara. Desa Taraitak Satu merupakan hasil pemekaran dari Desa Taraitak, yang dimekarkan pada tahun 2012. Secara administratif Desa Taraitak Satu berbatasan dengan :

Sebelah Utara : Desa Tember

Kecamatan Tompaso

Sebelah Selatan : Desa Kopiwangker dan

Desa Paslaten

Sebelah Barat : Desa Tumaratas

Sebelah Timur : Desa Taraitak

Desa Taraitak Satu memiliki luas wilayah $2,1 \mathrm{~km}^{2}$. Jarak desa dari Ibu Kota Kecamatan yakni Amongena adalah 3,3km dan berjarak $34 \mathrm{~km}$ dari Ibu Kota Kabupaten yakni Tondano, serta berjarak $55 \mathrm{~km}$ dari Ibu Kota Propinsi yakni Manado.

\section{Keadaan Penduduk}

Desa Taraitak Satu memiliki jumlah penduduk 931 jiwa dengan 332 KK. Distribusi penduduk menurut jenis kelamin dapat dilihat pada Tabel 1. 
Tabel 1. Penduduk Menurut Jenis Kelamin di Desa Taraitak Satu

\begin{tabular}{lccc}
\hline No & Jenis Kelamin & Jumlah & Persentase (\%) \\
\hline 1 & Laki - laki & 499 & 54 \\
2 & Perempuan & 432 & 46 \\
\hline & Total & $\mathbf{9 3 1}$ & $\mathbf{1 0 0}$ \\
\hline
\end{tabular}

Sumber : Kantor Desa Taraitak Satu, Tahun 2016

Tabel 1 menunjukkan bahwa jumlah perempuan lebih sedikit dari pada laki-laki. Namun, tidak berarti bahwa tenaga kerja perempuan lebih sedikit dari laki-laki. Bahkan sebaliknya, berdasarkan hasil penelitian, jumlah perempuan yang bekerja lebih banyak dari laki-laki.

Tabel 2. Mata Pencaharian Penduduk di Desa Taraitak Satu

\begin{tabular}{clcc}
\hline No & Mata Pencaharian & Jumlah Jiwa & Persentase (\%) \\
\hline 1 & Petani & 296 & 31,81 \\
2 & PNS & 41 & 4,41 \\
3 & Pengrajin & 1 & 0,11 \\
4 & Sopir & 1 & 0,11 \\
5 & Wiraswasta & 46 & 4,94 \\
6 & Karyawan Perusahaan & 17 & 1,82 \\
7 & Swasta & 13 & 1,39 \\
8 & Perangkat Desa & 4 & 0,43 \\
9 & TNI/Polri & 512 & 54,99 \\
\hline & Total & $\mathbf{9 3 1}$ & $\mathbf{1 0 0}$ \\
\hline
\end{tabular}

Sumber : Kantor Desa Taraitak Satu, Tahun 2016

Tabel 2 menunjukkan bahwa persentase total jiwa yang ada merupakan persentase dari jumlah penduduk yang bekerja. Dapat dilihat bahwa bertani merupakan mata pencaharian utama yang dilakukan oleh penduduk, yang didalamnya terdapat juga buruh tani yang bekerja pada kebun tomat milik dari masyarakat setempat yang terdapat di daerah penelitian, serta terdapat juga pedagang yang bekerja misalnya dengan memborong tomat yang diproduksi oleh petani dan kemudian memasarkannya.

\section{Sarana dan Prasarana}

Adapun sarana dan prasana yang ada di desa penelitian yaitu sekolah, balai desa, pusat kesehatan desa (puskesdes), jalan dan gereja. Untuk lebih jelasnya dapat dilihat pada Tabel 3 berikut:

\begin{tabular}{|c|c|c|c|}
\hline No & Sarana dan Prasana & Jumlah (unit) & Kondisi \\
\hline \multirow[t]{4}{*}{1} & Sekolah : & & \\
\hline & - TK & 2 & Baik \\
\hline & $-\mathrm{SD}$ & 1 & Baik \\
\hline & - SMA & 1 & Baik \\
\hline 2 & $\begin{array}{l}\text { Pusat kesehatan desa } \\
\text { (puskesdes) }\end{array}$ & 1 & Baik \\
\hline 3 & Balai Desa & 1 & Baik \\
\hline \multirow[t]{3}{*}{4} & Gereja : & & \\
\hline & - GMIM & 1 & Baik \\
\hline & - GPdI & 1 & Baik \\
\hline 5 & Jalan Desa & & Baik \\
\hline
\end{tabular}

Tabel 3 menunjukkan bahwa di daerah penelitian terdapat sekolah yakni TK sebanyak 2 unit, SD dan SMA masing-masing sebanyak 1 unit, gereja yakni GMIM dan GPdI masing-masing 1 unit, serta pusat kesehatan desa (puskesdes) dan balai desa masing-masing 1 unit. Adapun jalan yang ada di daerah penelitian kondisinya baik yaitu untuk jalan utama sudah diaspal beton, sedangkan untuk jalan di lorong diaspal kasar, dan angkutan sudah sangat lancar. Angkutan ke desa ini setiap saat ada baik roda 4 dan roda 2.

Untuk sarana pendidikan, pada umumnya baik karena gedungnya sudah permanen sehinga anak-anak tidak perlu lagi pergi ke desa lain untuk menuntut ilmu, bahkan ada banyak anak-anak di desa tetangga menuntut ilmu di Desa Taraitak Satu ini. Untuk sarana kesehatan, di Desa Taraitak Satu terdapat pusat kesehatan desa (puskesdes), tapi puskesdes ini hanya digunakan jika ada imunisasi untuk balita atau ada kegiatan kesehatan lainnya, sehingga warga masyarakat harus ke tempat lain untuk mendapatkan perawatan kesehatan.

\section{Karakteristik Petani Responden}

Karakteristik petani responden yang dimaksud meliputi: Umur, tingkat pendidikan formal, pengalaman bertani, jumlah tanggungan keluarga dan pendapatan diluar usahatani tomat. Untuk lebih jelasnya dapat dilihat pada Tabel 4 berikut ini:

\begin{tabular}{|c|c|c|c|}
\hline No & Karakteristik Petani Responden & Jumlah & $\begin{array}{c}\text { Persentase } \\
(\%)\end{array}$ \\
\hline \multirow[t]{4}{*}{1} & Umur : & & \\
\hline & $-26-35$ tahun & 5 & 25 \\
\hline & $-36-45$ tahun & 3 & 15 \\
\hline & $-46-60$ tahun & 12 & 60 \\
\hline & Jumlah & 20 & 100 \\
\hline \multirow[t]{4}{*}{2} & Tingkat Pendidikan Formal & & \\
\hline & - SMP & 6 & 30 \\
\hline & - SMA & 13 & 65 \\
\hline & - D3 & 1 & 5 \\
\hline & Jumlah & 20 & 100 \\
\hline \multirow[t]{4}{*}{3} & Pengalaman bertani : & & \\
\hline & $-5-10$ tahun & 8 & 40 \\
\hline & $-11-20$ tahun & 10 & 50 \\
\hline & $-\quad 21-25$ tahun & 2 & 10 \\
\hline & Jumlah & 20 & 100 \\
\hline \multirow[t]{4}{*}{4} & Jumlah tanggungan keluarga & & \\
\hline & $-1-2$ jiwa & 16 & 80 \\
\hline & $-3-4$ jiwa & 3 & 15 \\
\hline & - Tidak ada tanggungan & 1 & 5 \\
\hline & Jumlah & 20 & 100 \\
\hline
\end{tabular}

Tabel 4 menunjukkan bahwa Rata-rata umur petani responden adalah berumur 43 tahun. Dari ratarata tersebut dapat ditarik kesimpulan bahwa petani sampel masih berada pada usia produktif sehingga masih besar potensi tenaga kerja yang dimiliki petani responden dalam berusahatani untuk beberapa waktu yang akan datang.

Untuk tingkat pendidikan formal, rata-rata tingkat pendidikan petani responden adalah di tingkat SMA. Jadi dapat dikatakan bahwa pendidikan memiliki perbedaan yang besar, dimana hal ini akan dapat berpengaruh pada wawasan, pengetahuan serta cara berpikir dan bertindak petani perempuan dalam pengelolaan usahatani. 
Dari segi pengalaman bertani tomat, rata-rata petani sampel sudah mempunyai pengalaman kurang lebih 13 tahun, dalam hal ini sudah cukup baik dalam berusahatani tomat. Pengalaman bertani dapat berpengaruh pada pengetahuan dan wawasan petani didalam mengelola usahatani tomat. Semakin lama pengalaman bertani, maka semakin tinggi pula pengetahuan dan wawasan terhadap pengelolaan usahatani tomat tersebut.

Jumlah tanggungan keluarga pada petani sampel rata-rata sama yakni 1-2 jiwa. Dimana jumlah tanggungan keluarga ini akan berpengaruh pada pendapatan petani sampel dan ketersediaan tenaga kerja pada usahatani. Tanggungan keluarga juga dapat menjadi beban hidup bagi keluarga apabila tidak aktif bekerja. Ketersediaan tenaga kerja dalam keluarga merupakan faktor penting dalam usahatani, dimana tenaga kerja yang dimaksud adalah petani dan anggota keluarganya.

\section{Tahapan-Tahapan Kegiatan yang Melibatkan Perempuan pada Usahatani Tomat di Desa Taraitak Satu}

Dalam usahatani tomat terdapat beberapa tahapan kegiatan yang melibatkan perempuan, dimana secara umum akan diuraikan sebagai berikut:

\begin{tabular}{|c|c|c|c|c|}
\hline \multirow[t]{2}{*}{ Tabe } & 5. Tahapan-tahapan & \multicolumn{3}{|c|}{ Kegiatan yang Melibatkan } \\
\hline & $\begin{array}{l}\text { Perempuan Pada Us } \\
\text { Taraitak Satu }\end{array}$ & latani & Tomat & li Desa \\
\hline \multirow{2}{*}{ No } & \multirow{2}{*}{ Tahapan Usahatani Tomat } & \multicolumn{3}{|c|}{ Waktu } \\
\hline & & Hari & Mulai & Selesai \\
\hline 1 & Persiapan Bibit & 1 & 07.30 & 17.00 \\
\hline 2 & Pembersihan lahan & 1 & 07.30 & 17.00 \\
\hline 3 & $\begin{array}{l}\text { Pembedengan dan } \\
\text { pembuatan lubang tanam }\end{array}$ & 1 & 07.30 & 17.00 \\
\hline 4 & Pemulsaan & 1 & 07.30 & 17.00 \\
\hline 5 & Penanaman & 1 & 07.30 & 17.00 \\
\hline \multirow[t]{7}{*}{6} & Pemeliharaan, meliputi & & & \\
\hline & a. Penyiraman & 1 & 07.30 & 17.00 \\
\hline & b. Penyiangan & 1 & 07.30 & 17.00 \\
\hline & c. Pemupukan & 1 & 07.30 & 17.00 \\
\hline & d. Pemangkasan & 2 & 07.30 & 17.00 \\
\hline & e. Pengikatan & 2 & 07.30 & 17.00 \\
\hline & $\begin{array}{l}\text { f. Pemberantasan hama } \\
\text { dan penyakit tanaman }\end{array}$ & 1 & 07.30 & 17.00 \\
\hline 7 & Panen & 1 & 07.30 & 17.00 \\
\hline 8 & Pasca Panen & $1 / 4$ & 17.30 & 21.00 \\
\hline
\end{tabular}

\section{Persiapan Bibit Tomat}

Bibit tanaman tomat yang unggul dibeli di toko-toko pertanian. Kebanyakan para perempuan yang membeli bibit ini. Bibit tersebut kemudian di rendam selama rata-rata kurang lebih 1 hari, dan dimulai pukul 07.30 sampai pukul 17.00 wita. Biasanya ini dilakukan oleh para perempuan pemilik lahan, bukan dilakukan oleh buruh tani, namun pada kondisi tertentu ada juga perempuan buruh tani yang menyiapkan bibit tomat karena sudah di sewa oleh pemilik lahan.

2. Pembedengan dan Pembuatan Lubang Tanam
Lahan yang akan ditanami tomat sebelumnya dibersihkan dulu dari rumput-rumput yang tumbuh, dan kemudian tanah diolah dengan cara hati-hati agar lapisan humus tanah tidak hilang dan rusak. Untuk pembersihan lahan rata-rata perempuan memerlukan waktu1 hari dari pukul 07.30 sampai pukul 17.00 wita. Setelah tanah selesai dibersihkan dan diolah, maka tahap selanjutnya yakni pembedengan.Pada tahap pembedengan, rata-rata perempuan dapat menghabiskan waktu selama 1 hari dari pukul 07.30 sampai pukul 17.00 wita. Selanjutnya pembuatan lubang tanam. Tahap pembuatan lubang tanam, yakni sebelum pembuatan lubang tanam, maka terlebih dahulu ditentukan letak lubang tanam yang akan digali, dengan cara dipatok. Pembuatan lubang tanam ini dapat menghabiskan waktu kerja rata-rata selama 1 hari yang dimulai dari pukul 07.30 sampai pukul 17.00 wita. Dalam tahap ini, lamanya hari dan waktu kerja tergantung pada luas lahan dan jumlah tenaga kerja perempuan.

3. Penanaman

Setelah lahan dipersiapkan, maka tahap selanjutnya adalah penanaman. Penanaman ini dilakukan dengan cara, bibit yang sudah dipersiapkan dimasukkan kedalam lubang tanam, dan kemudian lubang ditutup kembali dengan tanah dengan cara, tanah dihamburkan ke dalam lubang. Tanah yang digunakan untuk menutup lubang hanya sedikit saja. Selanjutnya tanah disiram dengan air. Proses penanaman rata-rata perempuan membutuhkan waktu kerja selama 1 hari kerja dimulai pukul 07.30 sampai pukul 17.00 wita.

4. Pemulsaan

Tomat yang sudah selesai ditanam, di pasangkan plastik hitam. Pemasangan plastik ini berguna melindungi tanaman tomat dari berbagai hama seperti burung yang akan mencakar dan memakan bibit-bibit tomat yang baru ditanam. Mulsa plastik juga berguna untuk menahan air hujan, sehingga bibit tomat tidak terpencar. Pemasangan mulsa plastik ini hanya memakan waktu kerja rata-rata setengah hari saja yang dimulai 07.30 sampai pukul 12.00 wita, sehingga biasanya hanya 1-2 tenaga kerja perempuan yang dilibatkan.

5. Pemeliharaan

Terdapat beberapa tahap pekerjaan dalam pemeliharaan tanaman tomat, yang meliputi:

a. Penyiraman

Tanaman tomat harus disiram setelah berumur 2-3 minggu. Penyiraman dilakukan jika tanah kering, dan hanya jika musim kemarau saja. Jika musim hujan, tanaman tomat tidak perlu disiram. Penyiraman tanaman tomat ini biasanya hanya 1 tenaga kerja perempuan yang dilibatkan, dan waktu kerja yang diperlukan rata-rata1 hari 07.30 sampai pukul 17.00 wita. 
b. Penyulaman

Tanaman tomat yang tumbuh merana atau mati harus segera disulam dengan tanaman yang baru. Pemeriksaan terhadap tanaman tomat yang sudah ditanam biasanya ditentukan dengan cara sebagai berikut :

1) Setelah 1 minggu ditanam, kebun diperiksa tiap hari.

2) Tanaman berumur 2-4 minggu, diperiksa 1 kali per minggu.

Bibit yang digunakan untuk menyulam adalah bibit cadangan yang sudah disipak sebelumnya.

c. Pemupukan

Pemupukan pada tanaman bertujuan untuk :

1) Mencukupi kebutuhan unsure hara bagi tanaman.

2) Memperbaiki kondisi tanah sehingga akar tanaman dapat tumbuh dengan baik dan dapat menyerap unsur hara dengan jumlah yang cukup.

Jenis pupuk yang sering digunakan untuk tanaman tomat adalah pupuk buatan seperti: ponska, SP, urea, serta pupuk organik seperti pupuk kandang dan kompos. Pemupukan biasanya memerlukan waktu ratarata selama 1 hari dimulai 07.30 sampai pukul 17.00 wita.

d. Penyiangan

Penyiangan pada tanaman yang tumbuh disekitar tanaman tomat memerlukan waktu kerja rata-rata selama 1 hari kerja yang dimulai dari 07.30 sampai pukul 17.00 wita. Penyiangan dilakukan dengan teliti, karena bisa merusak tanaman tomat yang sudah tumbuh, oleh karena itu memerlukan waktu kerja yang lama untuk melakukannya. Penyiangan dilakukan, karena tanaman lain bisa mengambil unsur hara di sekitar tanaman tomat, sehingga jika tidak dibersihkan maka tanaman tomat bertumbuh tidak sempurna.

e. Pengikatan

Tanaman tomat yang berumur 4 minggu harus di ikat. Tanaman tomat ini diikatkan pada bambu yang sudah dipasang terlebih dahulu. Bambu yang dipasang merupakan bambu halus yang biasanya masyarakat setempat menyebutnya "patok". Bambu halus tersebut dipasang pada setiap tanaman tomat dalam hal ini 1 tanaman tomat dipasangkan 1 bambu halus. Pada tahap pemasangan bambu halus ini "patok, dilakukan oleh laki-laki.

Pengikatan tanaman tomat pada bambu berguna untuk menahan tanaman tomat dari angin, agar supaya tanaman tomat tidak mudah roboh. Pengikatan dilakukan selama kurang lebih 4 kali sampai tomat berumur 11 minggu. Pada tahap pengikatan ini, waktu kerja yang dibutuhkan rata-rata selama 2 hari kerja yang dimulai 07.30 sampai pukul 17.00 wita.

f. Pemangkasan

Tanaman tomat yang berumur kurang lebih 5 minggu harus di pangkas daun-daunnya. Daun yang dipangkas harus daun yang sudah tua. Pemangkasan daun dimulai dari bagian bawah tanaman sampai bagian tengah batang. Pemangkasan harus dilakukan, agar supaya sinar matahari tidak dihalangi oleh daundaun tersebut, sehingga tanaman tomat akan berbuah dengan baik. Jika daun tanaman tomat tidak dipangkas, maka buah tomat akan muncul bercak-bercak hitam, dan buahnya tidak bertumbuh sempurna. Waktu kerja yang diperlukan oleh responden rata-rata selama 2 hari kerja dan dimulai 07.30 sampai pukul 17.00 wita.

g. Pemberantasan hama dan penyakit tanaman

Tanaman tomat sedapat mungkin harus dihindarkan dari serangan hama dan penyakit tanaman, karena hama dan penyakit dapat menurunkan produksi dan mutu tomat yang dihasilkan. Bahkan akibat dari serangan hama dan penyakit menyebabkan tanaman tidak mau berbuah sama sekali, atau bahkan sering menyebabkan kematian. Pada tahap ini, yang melakukan pekerjaan tersebut adalah tenaga kerja lakilaki.

6. Panen (Pemetikan)

Tanaman tomat yang dirawat dengan baik biasanya sudah mulai berproduksi pada umur minggu, tergantung pada iklim. Pemetikan tomat membutuhkan waktu kerja rata-rata selama 1 hari kerja dimulai 07.30 sampai pukul 17.00 wita, tergantung pada tahap-tahap pemetikannya. Pemetikan tomat dilakukan beberapa tahap seperti :

1) Pemetikan Pendahuluan,

2) Petik banyak (panen raya), bisa berlangsung selama 10 kali,

3) Petik hijau (petik racutan) yang dilakukan dengan cara memetik semua buah yang masih tertinggal dan yang sudah merah maupun masih hijau.

7. Pasca Panen

Untuk mendapatkan tomat yang sudah siap diperdagangkan perlu adanya pengolahan atau pemilihan buah tomat. Prinsip dari pengolahan atau pemilihan buah tomat bertujuan untuk memisahkan tomat dari buah tomat yang busuk, pecah atau buahnya kurang bagus dengan buah tomat yang bagus. Pemilihan buah tomat biasanya hanya dilakukan oleh perempuan rata-rata selama setengah hari saja yang dimulai pukul 17.00 sampai dengan pukul 21.00.

\section{Curahan Tenaga Kerja Perempuan Pada Usahatani Tomat}

Tenaga kerja merupakan salah satu faktor produksi bersama-sama dengan faktor produksi lain dalam suatu proses produksi guna meningkatkan hasil pertanian. Curahan tenaga kerja yang dimaksud adalah tenaga kerja dalam keluarga yakni tenaga kerja perempuan (istri) dan tenaga kerja laki-laki (suami), serta tenaga kerja anak.

Kebutuhan tenaga kerja pada setiap usahatani berbeda-beda menurut komoditinya. Demikian juga dengan komoditi tomat yang memiliki tahap-tahap tertentu yang melibatkan perempuan dalam pelaksaannya. 
Rata-rata curahan tenaga kerja laki-laki dan perempuan pada setiap tahapan pekerjaan dalam usahatani tomat ditunjukan pada Tabel 6 berikut:

\begin{tabular}{|c|c|c|c|c|}
\hline \multirow{3}{*}{ Tahapan Pekerjaan } & \multirow{2}{*}{\multicolumn{4}{|c|}{ Curahan Tenaga Kerja }} \\
\hline & & & & Laki-laki \\
\hline & Jumlah & Persentase (\%) & Jumlah & Persentase (\%) \\
\hline 1. Persiapan Bibit & 12 & 60 & 8 & 40 \\
\hline 2. Pembersihan Lahan & 12 & 60 & 8 & 40 \\
\hline 3. Pembedengan dan Pembuatan Lubang Tanam & 11 & 55 & 9 & 45 \\
\hline 4. Pemulsaan & 12 & 60 & 8 & 40 \\
\hline 5. Penanaman & 12 & 60 & 8 & 40 \\
\hline 6. Pemeliharaan yang meliputi : & & & & \\
\hline a. Penyiraman & 14 & 70 & 6 & 30 \\
\hline b. Penyiangan & 13 & 65 & 7 & 35 \\
\hline c. Penyulaman & 14 & 70 & 6 & 30 \\
\hline d. Pemupukan & 14 & 70 & 6 & 30 \\
\hline e. Pemangkasan & 20 & 100 & - & - \\
\hline f. Pengikatan & 20 & 100 & & \\
\hline g. Pemberantasan hama dan penyakit & 7 & 35 & 13 & 65 \\
\hline 7. Panen & 14 & 70 & 6 & 30 \\
\hline 8. Panen dan Pasca Panen & 20 & 100 & - & - \\
\hline
\end{tabular}

Tabel 6 menunjukkan bahwa rata-rata curahan tenaga kerja perempuan pada tahap persiapan bibit lebih besar dari rata-rata curahan tenaga kerja laki-laki. Dimana rata-rata curahan tenaga kerja perempuan sebesar $60 \%$, dan curahan tenaga kerja laki-laki sebesar $40 \%$. Hal ini disebabkan karena pada tahap persiapan bibit tomat tidak terlalu membutuhkan kemampuan fisik yang kuat, sehingga tenaga perempuan yang lebih banyak bekerja didalamnya.

Pada tahap pembersihan lahan, curahan tenaga kerja perempuan sebesar $60 \%$, sedangkan curahan tenaga kerja laki-laki sebesar $40 \%$. Dari sini dapat dilihat bahwa curahan tenaga kerja perempuan pada tahap ini lebih besar dari pada curahan tenaga kerja laki-laki. Hal ini dikarenakan oleh ketekunan dan kerajinan tenaga kerja perempuan.

Pada tahap pembedengan dan pembuatan lubang tanam, curahan tenaga kerja perempuan masih lebih banyak dari pada curahan tenaga kerja laki-laki. Dimana, rata-rata curahan tenaga kerja perempuan sebesar 55\% dan curahan tenaga kerja laki-laki sebesar $45 \%$. Hal ini dikarenakan pada tahap ini, pekerjaan cukup sulit dilakukan, namun sebagian besar dari petani perempuan menekuni tahap ini dengan tujuan untuk menambah penghasilan keluarga.

Pada tahap pemulsaan, tenaga kerja perempuan lebih sedikit yaitu sebesar $60 \%$ dari pada curahan tenaga kerja laki-laki yaitu sebesar $40 \%$. Pada tahap ini pun cukup sulit dilakukan oleh perempuan, namun ada beberapa perempuan yang menekuni tahap ini karena sudah terbiasa bekerja.

Pada tahap pemeliharaan yang meliputi penyiraman, penyiangan, pemupukan, pemangkasan dan pengikatan, rata-rata curahan tenaga kerja perempuan sebesar $79 \%$, sedangkan curahan tenaga kerja laki-laki sebesar 31\%. Dari sini dapat dilihat bahwa curahan tenaga kerja perempuan lebih besar dari pada curahan tenaga kerja laki-laki. Hal ini dikarenakan oleh ketekunan dan kerajinan tenaga kerja perempuan.

Pada tahap pemberantasan hama dan penyakit tanaman, curahan tenaga kerja laki-laki lebih banyak daripada curahan tenaga kerja perempuan, yaitu sebesar $65 \%$ untuk curahan tenaga kerja laki-laki sedangkan $35 \%$ untuk curahan tenaga kerja perempuan. Hal ini karena pada tahap ini membutuhkan kemampuan fisik yang kuat sehingga tenaga kerja laki-laki lebih dibutuhkan, namun dalam beberapa kesempatan, ada beberapa sampel juga menekuni tahap ini.

Pada tahap panen/pemetikan, curahan tenaga perempuan sebesar $70 \%$ sedangkan curahan tenaga kerja laki-laki sebesar 30\%. Dari sini dapat dilihat bahwa curahan tenaga kerja perempuan lebih besar daripada curahan tenaga laki-laki, hal ini dikarenakan ketekunan dan kerajinan tenaga kerja perempuan. Namun, ada beberapa laki-laki pun dilibatkan dalam tahap panen ini untuk memikul hasil panen.

Pada tahap pengolahan hasil, umumnya tenaga kerja perempuan yang terlibat dalam tahap ini yakni sebesar $100 \%$, sedangkan curahan tenaga kerja laki-laki tidak dilibatkan. Dari sini dapat dilihat bahwa oleh karena ketekunan dan kerajinan para perempuan tani sehingga walaupun mereka sudah merasa lelah bekerja dari pagi sampai sore, mereka tetap melanjutkan pekerjaan untuk mengolah hasil panen tomat tersebut, ini semua dilakukan guna untuk menambah penghasilan keluarga.

\section{Pengaruh Faktor Sosial (Umur, Tingkat Pendidikan dan Pengalaman Bertani) Terhadap Curahan Tenaga Kerja Perempuan Pada Usahatani Tomat}

Faktor-faktor sosial yang diduga mempengaruhi curahan tenaga kerja perempuan pada usahatani tomat adalah umur, tingkat pendidikan dan pengalaman bertani. Umur yang dimaksud disini adalah usia petani responden yang berumur $>15$ tahun dan masih produktif.

Dalam kegiatan berusahatani, setiap terjadi peningkatan umur sebesar 1 tahun, akan terjadi penurunan curahan tenaga kerja perempuan. Ini dikarenakan kemampuan fisik dan ketahanan bekerja dari perempuan itu sendiri. Namun didaerah penelitian ini, faktor umur perempuan tidak siginifikan pengaruhnya terhadapa usahatani tomat. Hal ini disebabkan karena petani responden rata-rata memiliki umur yang produktif dan masih memiliki fisik yang kuat dalam mengelola usahatani tomat.

Tingkat pendidikan yang dimaksud disini adalah tingkat pendidikan formal yang pernah dijalani oleh petani sampel misalnya: SD, SMP, SMA, atau perguruan tinggi. Dalam kegiatan berusahatani, setiap terjadi peningkatan pendidikan sebesar 1 tahun, terjadi penurunan curahan tenaga kerja perempuan. Hal ini dikarenakan, semakin tingginya tingkat pendidikan, perempuan akan lebih mengutamakan untuk mencari pekerjaan lain sesuai dengan latar belakang pendidikan sampel selain dari berusahatani. Namun didaerah penelitian ini, faktor tingkat pendidikan tidak 
berpengaruh signifikan terhadap curahan tenaga kerja perempuan pada usahatani tomat. Hal ini disebabkan karena tingkat pendidikan merupakan tingkat pendidikan formal, yang tidak berhubungan langsung dengan usahatani petani sampel. Namun, ada beberapa sampel yang berlatarbelakang pendidikan perguruan tinggi, tapi berusahatani tomat. Ini dilakukan karena untuk menambah penghasilan keluarga mereka.

Pengalaman bertani yang dimaksud disini adalah lamanya petani responden berusahatani tomat yang dinyatakan dalam tahun. Setiap terjadi peningkatan pengalaman bertani sebesar 1 tahun, terjadi peningkatan curahan tenaga kerja perempuan.

Pengaruh pengalaman bertani sangat siginifikan terhadap curahan tenaga kerja perempuan pada usahatani tomat dan memiliki hubungan yang positif antara pengalaman bertani dengan curahan tenaga kerja perempuan pada usahatani tomat. Makin banyak pengalaman bertani, maka curahan tenaga kerja perempuan semakin besar. Hal ini disebabkan karena, pemilik lahan akan lebih mencari tenaga kerja perempuan yang berpengalaman pada usahatani tomat karena selain menghemat waktu kerja dimana cara kerja perempuan yang berpengalaman lebih cepat daripada yang belum berpengalaman, juga untuk membuat hasil tanaman tomat lebih baik. Ini akan sangat menguntungkan bagi petani sampel yang memiliki banyak pengalaman dalam berusahatani tomat.

\section{Pengaruh Faktor Ekonomi (Luas Lahan, Jumlah Tanggungan Keluarga dan Pendapatan di Luar Usahatani Tomat) Terhadap Curahan Tenaga Kerja Perempuan Pada Usahatani Tomat}

Luas Lahan merupakan salah satu faktor yang berperan dalam kegiatan usahatani. Luas lahan yang dimaksud disini adalah luas lahan pertanaman tomat yang diusahakan oleh petani. Setiap terjadi peningkatan luas lahan, maka akan terjadi peningkatan curahan tenaga kerja pada usahatani tomat.

Dari hasil penelitian, sangat berpengaruh terhadap besarnya curahan tenaga kerja perempuan pada usahatani tomat. Ini berarti semakin luas lahan maka curahan tenaga kerja perempuan pada usahatani tomat semakin besar. Hal ini akan sangat menguntungkan bagi perempuan yang berusahatani tomat, dimana mereka akan mendapatkan penghasilan yang lebih besar jika luas lahan yang dikerjakan pun besar.

Jumlah tanggungan keluarga yang dimaksud adalah banyaknya yang ditanggung oleh perempuan dalam rumah tangga. Tanggungan keluarga merupakan salah satu sumber daya manusia pertanian yang dimiliki oleh petani, terutama yang berusia produktif dan menjadi beban hidup bagi keluarga apabila tidak bekerja.
Berdasarkan hasil penelitian bahwa jumlah tanggungan keluarga tidak terlalu berpengaruh signifikan terhadap besarnya curahan tenaga kerja perempuan pada usahatani tomat. Jumlah tanggungan keluarga akan berpengaruh pada pendapatan perempuan pada usahatani tomat, karena semakin banyak jumlah tanggungan keluarga, akan semakin besar kebutuhan dalam keluarga tersebut. Jika pendapatan suami sedikit, maka kehidupan keluarga tidak akan terpenuhi. Hal inilah yang mendorong para perempuan di Desa Taraitak Satu untuk berperan ganda dengan menjadi buruh pada usahatani tomat guna untuk menambah penghasilan keluarga.

Usaha memenuhi kebutuhan keluarga petani yaitu mencari sumber mata pencaharian tambahan. Pendapatan diluar usahatani tomat yang dimaksud disini adalah pendapatan yang diperoleh diluar usahatani tomat, baik dari usahatani, ternak maupun non-usahatani.

Berdasarkan hasil penelitian bahwa, pendapatan diluar usahatani tomat cukup berpengaruh terhadap tambahan pendapatan keluarga. Tetapi pada umumnya perempuan di Desa Taraitak Satu tetap mengolah dan menjadi buruh tani usahatani tomat, karena ada beberapa tahap pekerjaan yang harus dilakukan dalam produksi usahatani tomat yang dapat menjadi tabungan bagi mereka.

\section{Sikap Perempuan Terhadap Peran Ganda Pada Usahatani Tomat}

Sikap perempuan terhadap peran gandanya pada usahatani tomat diketahui dengan melihat jawaban-jawaban perempuan di Desa Taraitak Satu terhadap pernyataan-pernyataan yang diberikan. Pernyataan ini dibagi dalam 3 tahap yaitu pertama, merupakan pernyataan umum mengenai keadaan keluarga pada umumnya dan kegiatan keluarga yang diikuti, kedua, pernyataan untuk perempuan dalam hal ini istri mengenai pendapat mereka dalam peran ganda pada usahatani tomat serta curahan waktu kerja perempuan dalam keluarga dan dalam usahatani tomat, dan ketiga, merupakan pernyataan untuk suami dan anak mengenai peran dan pendapat mereka terhadap peran ganda perempuan pada usahatani tomat. Sikap perempuan terhadap peran gandanya pada usahatani tomat dapat dilihat pada Tabel 7 berikut ini.

Tabel 7. Sikap Perempuan Terhadap Peran Gandanya Pada Usahatani Tomat di Desa Taraitak Satu

\begin{tabular}{clcc}
\hline No & Kategori & Jumlah (Orang) & Persentase (\%) \\
\hline 1 & Setuju & 13 & 65 \\
2 & Kurang Setuju & 2 & 10 \\
\hline 3 & Tidak Setuju & 5 & 25 \\
\hline & Total & $\mathbf{2 0}$ & $\mathbf{1 0 0}$
\end{tabular}

Sumber : Data Primer, Tahun 2017

Tabel 7 menunjukkan bahwa dari 20 perempuan responden, banyaknya perempuan yang menjawab setuju terhadap peran gandanya pada usahatani tomat sebanyak 13 orang atau $65 \%$, yang 
menjawab kurang setuju sebanyak 2 orang atau $10 \%$, dan yang menyatakan tidak setuju dengan peran gandanya pada usahatani tomat sebanyak 5 orang atau 25\%. Dengan demikian dapat dikatakan bahwa sikap perempuan terhadap peran gandanya pada usahatani tomat di Desa Taraitak Satu lebih dominan setuju dari pada kurang setuju dan tidak setuju. Hal ini dikarenakan kesadaran perempuan yang setuju untuk berperan ganda guna untuk menambah penghasilan keluarga dan untuk memenuhi kebutuhan hidup keluarga mereka.

\section{Masalah-Masalah Yang Dihadapi Perempuan Dalam Peran Ganda Pada Usahatani Tomat di Desa Taraitak Satu}

1. Masalah Internal

Yang dimaksud dengan masalah internal adalah persoalan atau masalah yang timbul dalam diri pribadi sang perempuan tersebut. Ada diantara para perempuan yang lebih senang jika dirinya benar-benar hanya menjadi ibu rumah tangga, yang sehari-hari berkutat berkutat dirumah dan mengatur rumah tangga. Namun, keadaan menuntutnya untuk bekerja dan menyokong keuangan keluarga. Kondisi tersebut mudah menimbulkan stress karena bekerja bukanlah timbul dari keinginan diri namun seakan tidak punya pilihan lain demi membantu ekonomi keluarga. Biasanya, para perempuan yang mengalami masalah demikian, cenderung merasa sangat lelah karena seharian memaksakan diri untuk bertahan dikebun tomat. Dari 20 perempuan sampel yang diwawancarai terdapat 5 orang atau sebesar $25 \%$ petani sampel yang merasakan masalah ini.

2. Masalah Eksternal

a. Dukungan Suami

Dukungan suami dapat diartikan sebagai sikap penuh pengertian yang ditunjukan dalam bentuk kerjasama yang positif, ikut membantu menyelesaikan pekerjaan rumah tangga, membantu mengurus anak-anak serta memberikan dukungan moral dan emosional kepada istri. Didaerah penelitian, dukungan yang diberikan suami kebanyakan adalah dukungan moral dan emosional saja, sedangkan membantu mengurus anak dan menyelesaikan tugas rumah tangga adalah pekerjaan istri. Hal ini disebabkan karena di daerah penelitian, suami juga ada yang ikut bersama-sama bekerja dengan istri di kebun, beternak, berdagang, tukang ojek, buruh bangunan dan lain-lain, dan masih ada sistem patriarchal yang menganggap bahwa yang mengerjakan tugas rumah tangga itu adalah istri. Dari 20 perempuan sampel terdapat 10 orang atau sebesar $50 \%$ perempuan yang mengalami masalah ini.

\section{b. Kehadiran Anak}

Masalah pengasuhan terhadap anak biasanya dialami oleh petani sampel yang memiliki anak masih kecil. Dari 20 perempuan sampel, terdapat 2 orang atau sebesar $10 \%$ perempuan yang masih memiliki anak yang masih kecil. Biasanya anak tersebut dibawah ke kebun, karena di kebun terdapat rumah kecil sederhana yang biasa disebut "terung" oleh masyarakat Desa Taraitak1, atau juga anak tersebut ditinggalkan kepada orangtua atau saudara mereka yang tidak ada pekerjaan lain. Sedangkan sisanya sebanyak $90 \%$, hal ini tidak menjadi masalah karena setidaknya anak mereka sudah besar, minimal sudah bisa mengurus dirinya sendiri dan tidak merepotkan orang tua di kebun.

c. Beban Kerja Yang Berat

Beban kerja yang berat dialami oleh semua perempuan sampel. Hal ini membuat mereka sangat lelah. Kelelahan inilah yang sering membuat mereka sensitif dan emosional baik terhadap anak-anak, suami, maupun lingkungan masyarakat dimana perempuan tersebut tinggal. Apalagi anak-anak yang sudah besar tidak bisa diajak untuk bekerja sama.

\section{Upaya-Upaya Yang dilakukan Perempuan Untuk Menghadapi Masalah Peran Ganda Perempuan Pada Usahatani Tomat}

1. Untuk menghadapi masalah yang timbul dari diri sendiri, maka perempuan sampel mengatasinya dengan memberikan motivasi pada diri sendiri. Mereka juga menyadari bahwa mereka bekerja adalah untuk diri mereka sendiri dan anak-anaknya. Mereka ingin memberikan yang terbaik bagi anakanaknya. Mereka menyadari bahwa untuk mengatasi masalah yang timbul dari diri sendiri, harus diatasi dari diri sendiri juga.

2. Tidak terlalu banyak menuntut pada suaminya. Mereka butuh saling pengertian dan kerjasama untuk menghidupi keluarga dan member yang terbaik bagi anak-anak mereka sesuai dengan kemampuan mereka. Masalah pekerjaan keluarga dilakukan dengan ikhlas dan menerima bahwa itu merupakan tugas mereka untuk membantu suami, karena sudah menjadi adat dan kebiasaan di daerah penelitian. Mereka senang jika suami juga rajin bekerja bukan hanya bersantai-santai saja.

3. Di daerah penelitian, responden sering membawa anaknya ke kebun. Kebun menjadi rumah kedua bagi mereka karena disana juga

Agrisosioekonomi:

Jurnal Transdisiplin Pertanian (Budidaya Tanaman, Perkebunan, Kehutanan, Peternakan, Perikanan), Sosial dan Ekonomi 
tersedia rumah kecil "terung" yang bisa sebagai tempat beristirahat bagi mereka.

4. Untuk mengatasi beban kerja yang berat, maka perempuan membagi tugasnya pada anak-anaknya setelah pulang sekolah. Anakanaknya terlebih dahulu diberi pengertian untuk ikut membantu orang tua. Oleh karena itu perempuan harus mengatur waktu dengan keluarga dan perkerjaan mereka sehingga semua perannya dapat terselesaikan.

Secara serentak ada pengaruh faktor sosial dalam hal ini umur, tingkat pendidikan formal, dan pengalaman petani terhadap curahan waktu kerja perempuan pada usaha tani tomat. Pengalaman bertani sangat berpengaruh terhdap curahan tenaga waktu kerja perempuan karena semakin lama pengalaman bertani perempuan akan semakin banyak dibutuhkan oleh para petani tomat. Sedangkan faktor umur dan tingkat pendidikan formal tidak berpengaruh terhadap curahan tenaga waktu kerja perempuan pada usaha tani tomat.

Faktor ekonomi dalam hal ini luas lahan, jumlah tanggungan keluarga, dan pendpatan diluar usaha tani tomat sangat berpengaruh terhadap pendapatan dan waktu kerja perempuan dalam usaha tani tomat. Luas lahan sangat berpengaruh terhadap curahan waktu kerja dan pendapatan perempuan karena semaki besar luas lahan yang diusahakan akan semakin besar juga curahan waktu kerja perempuan dan pendapatan pada usaha tani tomat. Sedangkan jumal tanggungan keluarga dan pendapatan diluar usaha tani tomat tidak berpengaruh terhdap curahan waktu kerja perempuan tetapi sangat berpengaruh pada pendapatan dalam keluarga. Semakin banyak jumlah tanggungaan keluarga semakin banyak yang harus dipenuhi kebutuhannya oleh perempuan tersebut.

Sikap perempuan terhadap peran gandanya dalam usaha tani tomat yang bersikap setuju sebanyak $65 \%$, yang bersikap kurang setuju $10 \%$ dan yang bersikap tidak setuju $25 \%$.

\section{KESIMPULAN DAN SARAN}

\section{Kesimpulan}

1. Tahap-tahap pekerjaan yang melibatkan perempuan pada usaha tani tomat yaitu pada tahap persiapan bibit, pembersihan lahan, pembedengan dan pembuatan lubang tanam, pemulsaan, (penyiraman, penyiangan, pemupukan, pemangkasan, dan pengikatan), panen, pasca panen.

2. Curahan tenaga kerja perempuan yang paling dominan ada pada tahapan pemeliharaan, hal ini dikarenakan pada tahap ini, ada beberapa proses yang harus dilalui dalam berusahatani tomat yakni tahap penyiraman, penyiangan, pemupukan, pemangkasan dan pengikatan.

3. Curahan waktu kerja perempuan dalam usahatani tomat yang tertinggi yaitu pada tahap pemeliharaan, khususnya ditahap pemangkasan dan pengikatan, karena pada tahap ini, waktu kerja perempuan dalam usahatani tomat memerlukan waktu 2 hari.

1. Kepada petani

\section{Saran}

Diharapkan kepada seluruh anggota keluarga petani agar supaya ada kerja sama yang baik didalam keluarganya sehingga dapat meningkatkan kesejahteraan mereka. Diharapkan kepada petani untuk membuka diri terhadap perkembangan teknologi dan pengetahuan sehingga dapat menambah wawasannya.

2. Kepada pemerintah

Diharapkan kepada pemerintah untuk mengadakan penyuluhan pertanian sehubungan dengan usaha tani tomat sehingga dapat menambah pengetahuan dan keterampilan masyarakat. Diharapkan pemerintah dapat membuat program pemberdayaan perempuan sehingga dapat meningkatkan kesejahteraan keluarga mereka.

\section{DAFTAR PUSTAKA}

Listiani. 2002. Gender Dan Komunitas Perempuan Pedesaan. Bitra Indonesia: Medan.

Soetomo. 2008. Masalah Tenaga Kerja Indonesia dan Upaya Pemecahannya. Yogyakarta: Pustaka Pelajar.

Sugihastuti. 2000. Wanita Dimata Wanita. Yayasan Adikarya IKAPI Dan The Lord Foundation: Yogyakarta. 